\title{
恒常性創発に向けた振動子の集合体としてのロボ ツト自律制御による動的対象への同期
}

\section{An Adaptability of the Oscillator Aggregation Based Robot Control to Synchro- nize Dynamical Behaviors of the External Object as an Emergence of Homeosta- sis}

\author{
山内 翔 公立はこだて未来大学 \\ Sho Yamauchi Future University Hakodate \\ yamauchi@fun.ac.jp
}

鈴木 恵二
Keiji Suzuki

keywords: oscillator, synchronization, homeostasis

\section{Summary}

In the dynamic environment, how the robot can be controlled is an important issue. Robot would be surrounded by lots of energy flows. Such energy flows are often oscillatory and there are regularity. In spite of the absence of neural circuits, simple living organisms such as amoebas show homeostatic behavior against such energy flows. This is because amoebas are constructed as oscillator aggregation and they can be synchronized with oscillating objectives and some regular motions. In this study, the amoeba-like dynamics was focused as a possible mechanism to control the robot body motion fit for the purpose to stabilize relationship between robot and environment by synchronization. We proposed an oscillator aggregation based robot control mechanism to synchronize with oscillating objects in the external environment by using coupling van der Pol oscillators with a stochastic perturbation. In the real robot experiment, the robot demonstrated to maintain the own internal activity fit for the movement of external objects as a result of the synchronization, which was evaluated in the multivariate multiscale entropy analysis as an index of the degree of synchronization in complex cases. Synchronization and protective behavior observed in this experiment suggest a possible adaptability or autonomy of the robot to synchronize dynamical behaviors in the external environment as an emergence of homeostasis.

\section{1. は じめに}

生物には自身の構造や状態を安定に保つ性質である恒 常性が見られる.生物体では各器官が相互に連携し, 全体 として統一した調整がなされている.この性質により, 環 境の変化に適応し, 多彩な生命活動を行っている.このよ うな適応的性質は神経回路を有していない生物において も観測されている.粘菌における事例では, 一定間隔で加 えられる刺激を予測して回避行動をとる様子が観測され ている [Saigusa 08]. これは粘菌の細胞一つ一つが振動子 として働いており,その集合体として活動することによ り, 全体として同期することで発生した現象であると考え られている. そこで本稿では生物における恒常性のよう な適応的性質を, ロボットシステムにおいて実現する手法 について考える. 著者らはそうしたシステムの実現に向 けてロボットを振動子集合とみなし周囲環境に同期し,か つロボット自身の活動を維持するロボット自律制御を提 案し, 静的対象に対してその有効性を検証した [山内 15].
そこで本稿ではこのロボット自律制御手法の効果を動的 対象に対して確認する.また, 一般にノイズが存在する場 合の振動子間の同期はその同期状態と非同期状態の分離 が困難であり [Pikovsky 02], ロボットを振動子の集合体 として構築した場合, 実環境における実験で対象の変化に 同期したかどうかを判定することは難しい. そこで時系 列データの複雑さを測る手法である Multi-scale Entropy Analysis(MSE 解析) を利用してその同期判定を行う。さ らに応用例としてロボットが動的対象と強制同期及び相 互同期する事例を挙げ, 実際にそれら対象と同期し, かつ ロボット自身の活動を維持可能であることを示す.

\section{2. 設 計 思 想}

地球や生物は非平衡開放系であり, その内部ではエネル ギーや物質の流れが常に存在する [蔵本 07, Strogatz 03]. これらは互いに密接に関係しており,例えば地球の気候 の変動は生物に影響を及ぼし [Kleidon 05], また, 生物に 
は概日リズムなど地球の周期的な活動に合わせた仕組み が存在する [Sassone-Corsi 98]. そのため,ロボットが実 環境に適応し, 活動範囲を広げるためには, このような周 期性を持つ対象に適応する必要がある (図 1). また, 生物 において見られる適応は相互作用する対象が厳密に周期 的な場合にかぎらない. 粘菌においては, 一定の間隔で刺 激を加えた後にその刺激を一旦止めたとしても，一定時 間後にもう一度刺激を加えれば再度予測的な動きを見せ る [Saigusa 08]. 一方でロボットは自身の行動や活動を維 持し, 与えられた目標を達成しなくてはならない. よって, ロボットが実環境に適応し, 活動範囲を広げるためには, 周期性を持つものや何らかの規則性を持つ対象に同期し， 互いの関係を安定化させ,かつロボット自身の活動を維持 する必要がある. そのため, 周囲の周期性を持つものや何 らかの規則性を持つ対象に同期する機能と自身の活動を 維持するための調整機能を両立できるメカニズムとして 振動子を取り上げる.ロボット自身を仮想的に振動子の集 合として構築し, 周囲環境に同期し関係を安定させつつ, 自身の活動を維持する制御手法を構築する (図 2).なお, 本論文では同期は位相差固定状態の振動数同期のことを 指すものとする.

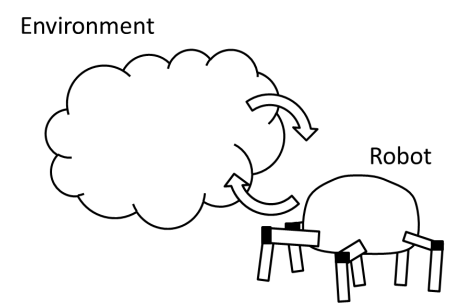

図 1 Interaction between environment and robot

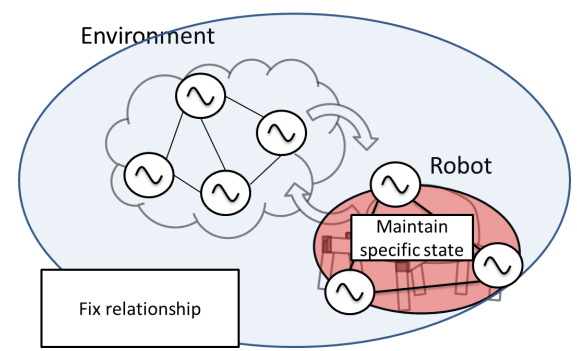

図 2 Interaction as oscillator aggregation to maintain both relationship and specific state

\section{3. 振動子集合の相互作用による制御手法}

$n$ 個の振動子の集合を考える.このうち, 振動子 $k$ の状 態を $x^{(k)}$ とした場合, 各振動子のダイナミクスを次のよう に定める.

$$
\frac{d^{2} x^{(k)}}{d t^{2}}=f_{o}^{(k)}+f_{s}^{(k)}+f_{\text {prob }}^{(k)}
$$

以下, 右辺の 3 つの項について説明する.

\section{1 $f_{o}$ : 拡張 van der Pol 振動子}

各振動子は van der Pol 振動子を元にして設計する. 項 $f_{o}$ は van der Pol 振動子としての動作を表現する項とす る.van der Pol 振動子は以下のようなダイナミクスを持つ.

$$
\frac{d^{2} x}{d t^{2}}+\lambda\left(x^{2}-1\right) \frac{d x}{d t}+x=0
$$

ここで, $\lambda$ は任意の定数である.この振動を, 原点周りの 振動から $x_{d}$ 周りの振動にし, また振幅を $\frac{1}{c_{o}}$ 倍したものと して次のように表現する.

$$
\frac{d^{2} x}{d t^{2}}+\lambda\left\{c_{o}^{2}\left(x-x_{d}\right)^{2}-1\right\} \frac{d x}{d t}+\left(x-x_{d}\right)=0
$$

ここで, $c_{o}$ は任意の定数である.これらから, 振動子 $k$ が $x_{d}^{(k)}$ 周りで振動するものとし,

$$
f_{o}^{(k)}=-\lambda\left\{c_{o}^{2}\left(x^{(k)}-x_{d}^{(k)}\right)^{2}-1\right\} \frac{d x^{(k)}}{d t}-\left(x^{(k)}-x_{d}^{(k)}\right)(4)
$$

とする。

\section{$3 \cdot 2 f_{s}$ : 状 態同期 項}

振動子同士を同期させるためには, 相互作用が必要とな る. 今回は以下のように単純な場合を考える.

$$
f_{s}^{(k)}=c_{s} \sum_{i}^{n}\left(x^{(i)}-x^{(k)}\right)
$$

ただし $c_{s}$ を正定数とする.

\section{$3 \cdot 3 f_{\mathrm{prob}}$ :摇らぎ項}

いま, 時刻 $t$ における全体の不安定度 $\varepsilon(t)$ を考える.これ は現状態がどの程度望ましいかを表すものとし, $0 \leq \varepsilon(t) \leq$ 1 とする. 項 $f_{\text {prob }}$ は時刻 $t$ における不安定度に比例した 摇らぎを与えるものである. $f_{\mathrm{prob}}$ を以下のように定める.

$$
f_{\text {prob }}^{(k)}=c_{\text {prob }} \varepsilon(t) u
$$

ただし, $c_{\text {prob }}$ は正定数, $u$ は区間 $(-0.5,0.5)$ の一様乱数と する.この定義により, 不安定度に比例して振動子の集合 が他の安定状態に遷移する確率が増大寸る [Pikovsky 02]. このような摇らぎの定義は生物における事例からも自然 なものであると考える [Saigusa 08].

\section{$3 \cdot 4$ 振 幅の 抑 制}

さらに, 不安定度の大きさに従って振動を拡大縮小する 作用を導入する. 時刻 $t$ における式 (4) の係数 $c_{o}$ を時刻 $t$ における不安定度 $\varepsilon(t)$ を用いて次のように定める.

$$
c_{o}(t)=\frac{a_{b}}{\left(\frac{a_{b}-a_{s}}{a_{s}}\right) \varepsilon(t)+1}
$$

ただし,$a_{b}>a_{s}>0$ かつ $a_{b}, a_{s}$ は定数とする. $a_{b}, a_{s}$ は最 大振幅と, 最小振幅を決定する係数で, 振幅は $\varepsilon(t)$ が最小 の 0 のときに $\frac{1}{a_{b}}$ 倍されて最小となり,また $\varepsilon(t)$ が最大の 
1 のときに振幅が $\frac{1}{a_{s}}$ 倍されて最大となるように設計して いる.これにより不安定度 $\varepsilon(t)$ の変化で, リミットサイク ルは常に変化する.この変化が $\varepsilon(t)$ を大きく減少させる ものである場合, 図 3 のように通常のリミットサイクル 軌道とは異なる動きを生み出す場合がある.

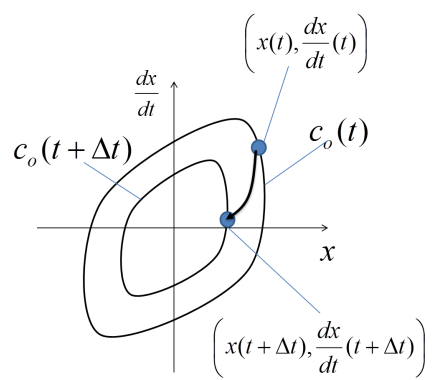

図 3 Change of limit cycle in different $\varepsilon(t)$ value

\section{$3 \cdot 5$ センサ入力の仮想振動子化と振動子のアクチュエー 夕出力}

自律ロボット内の入出力（制御）系において, 振動子の 組み込み方法を定義する.ここでは, 自律ロボットの入力 であるセンサと出力であるアクチュエータを仲介するダ イナミクスを振動子として扱い, 本稿では, どの入出力系 を振動子として記述するかということを, 振動子の割り当 てと呼ぶこととする.自律ロボット中の各センサからの 入力はそれぞれ仮想的に振動子の状態值として考えるこ ととする. 今, 振動子 $k$ がセンサに割り当てられている場 合はその割り当てられたセンサ入力を $v$ とすると $x^{(k)}=v$ となる.これにより, センサ以外に割り当てられている振 動子, すなわちアクチュエータに割り当てられた振動子 はセンサが割り当てられている振動子に対して同期して いくこととなる.一方でロボットのアクチュエータは, ア クチュエータが割り当てられた振動子の状態值が変換さ れることにより制御される. サーボの角度やモータの速 度などアクチュエータの制御パラメータの最小值を $a_{\mathrm{min}}$, 最大值を $a_{\mathrm{max}}$, 振動子 $k$ の状態值の最小值, 最大值をそれ ぞれ $x_{\min }, x_{\max }$ とするとアクチュエータの実際の制御パ ラメータ $a$ は

$$
a=\frac{x^{(k)}-x_{\min }}{x_{\max }-x_{\min }}\left(a_{\max }-a_{\min }\right)+a_{\min }
$$

とする。

\section{$3 \cdot 6$ 自律ロボットへ適用した場合の効果}

この制御手法を自律ロボットへ適用した場合, 次のよう な効果が期待できる. $n_{m}$ 個の制御パラメータと $n_{l}$ 個のセン サ入力を受ける自律システムを考える.ただし, $n_{m}+n_{l}=n$ とする.これら制御パラメータとセンサ入力を振動子の 状態值 $x^{(k)}$ に割り当てることとする.このうち, 制御パラ メータを割り当てられた振動子は, 自らの制御により状態
值を変化させることができるが, センサ入力を状態值とし て与えられる振動子は, その值を自ら変更することがで きない. いま, センサ入力が割り当てられた振動子 $l$ の状 態值が時間 $\Delta t$ のうちに $\Delta x_{l}$ 変化したとすると, 制御パラ メータが割り当てられた振動子 $k$ の式 (1) は

$$
\frac{d^{2} x^{(k)}}{d t^{2}}=f_{o}^{(k)}+\left(f_{s}^{(k)}+\Delta f_{s}^{(k)}\right)+f_{\mathrm{prob}}^{(k)}
$$

$\Delta f_{s}^{(k)}=c_{s} \Delta x_{l}$

となり, $\Delta f_{s}^{(k)}$ だけセンサ変化の影響を受けることになる. $\Delta f_{s}^{(k)}+f_{\mathrm{prob}}^{(k)}$ の值の大きさに応じて次の現象が起きる.

（1）值が振動子間の位相関係を維持不可能なほど大き な值でない場合

振動子 $k$ は自らの状態值を変更しながら他の振動子 と同期して安定状態に至る

（2）值が振動子間の位相関係を維持不可能なほど大き な值である場合

別の安定状態に至るために振動子間の位相関係を再 構築する

このような性質から,この制御手法を適用することで, セ ンサ值を振動子の状態值として入力された場合, その変 動が小さなものであればシステム全体でパラメータ同士 が同期し安定状態に至り, 大きければ新たな安定状態を 探しだす。これはすなわちセンサ情報との同期を保つこ とと不安定度で表される自身の活動の維持を両立する場 合, 両者は場合によっては相反することもあるが, 両者の バランスを保ちながら出来る限り両者とも満たす状態を 模索するシステムであると考える.

\section{4. 動的対象との同期とその判定法の提案}

振動子による制御手法が動的対象に対して効果を有す るかを評価するため, 特定のパターンで前後運動する対象 への同期実験を行う. 本稿での実験はすべて差分駆動型車 両ロボットを利用する。ロボットにはカメラが搭載され ており, 前方の映像を取得することができる.このロボッ トのアクチュエータには Mercury Motor SM-42BYG011 を用いており,静止トルクは $0.23 \mathrm{~N} \cdot \mathrm{m}$, ロボットの総重量 は $0.97 \mathrm{~kg}$ である.この実験におけるシステム構成を図 4 に示す.今回は, 図のように PC とロボットを配置し, それ ぞれ実験室内のネットワークに接続しておく.ロボットは 無線 LAN 接続によって PC からアクチュエータであるス テッピングモータの速度のデータを受け取り, その指示通 りにステッピングモータを回転させる.一方で, ロボット に搭載されているカメラからはその映像が PC へとスト リーミングされ, PC 側でその情報を元に振動子の状態值 を計算する. まず，この実験設定を図 5 に示す. 動的対 象は実験に用いるロボットと同型のロボットとする.ただ し,カメラは利用しない.ロボットと動的対象を $60 \mathrm{~cm}$ 離 


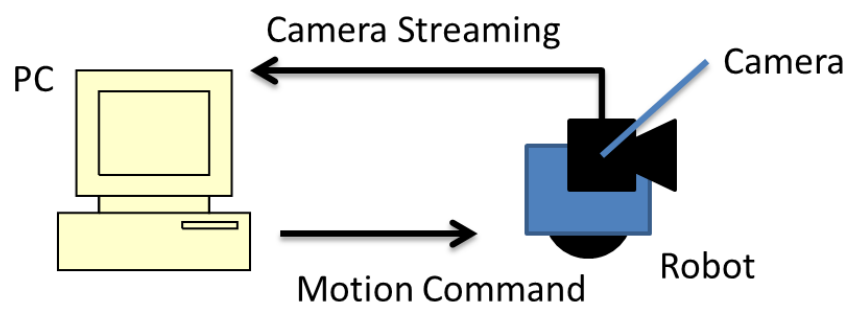

図 4 Experimental system configuration for synchronization

して配置する.このときロボットは色抽出によりカメラで 捉えている動的対象の重心位置とその面積をセンサ情報 として得ることができるものとする.このロボットを 4 つの振動子で制御する.このうち 2 つをセンサ入を割り 当てる振動子として,残りの 2 つをステッピングモータに 割り当てるものとする. センサにはカメラから得られた, 動的対象の重心位置とその面積を与える (図 6). $s_{R}$ と $s_{L}$ をそれぞれ右と左のステッピングモータのスピードとす る.これらは以下のように定められる.

$$
\begin{aligned}
& s_{R}=x^{(4)}\left(s_{\max }-s_{\min }\right)+s_{\min } \\
& s_{L}=x^{(3)}\left(s_{\max }-s_{\min }\right)+s_{\min }
\end{aligned}
$$

ただし, $s_{\max }$ 及び $s_{\min }$ はそれぞれステッピングモータの 最高速度と最低速度とする. $v$ と $p$ をそれぞれ現在カメラ で捉えている動的対象の面積とその重心位置とする.この とき $x^{(1)}$ と $x^{(2)}$ は次のように定める.

$$
\begin{aligned}
& x^{(1)}=\frac{v}{v_{\max }} \\
& x^{(2)}=\frac{p}{p_{\max }}
\end{aligned}
$$

ただし, $v_{\max }, p_{\max }$ はそれぞれカメラで捉える最大面積と 重心位置の取りうる最大值とする.この実験では $\varepsilon(t)$ を 次のように定める.

$$
\left.\varepsilon(t)=\frac{1}{2}\left(\mid v-v_{\text {ideal }}\right)|+| p-p_{\text {ideal }} \mid\right)
$$

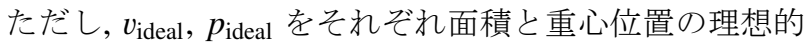
な值とする.この值は人手で定められる。本制御手法中 の係数は $\lambda=1.0, m_{b}=30, m_{s}=2.5, c_{p}=0.1, f_{s}=0.2$, $f_{\text {prob }}=0.1, v_{\text {ideal }}=\frac{1}{8} v_{\max }, p_{\text {ideal }}=0.5 p_{\text {max }}$ とした. また, 振 動子の割り当ては以下のようである.

- $x^{(1)}$ : トラッキング対象の面積（センサ）

・ $x^{(2)}$ : トラッキング対象の重心位置（センサ）

- $x^{(3)}$ : ステッピングモータ左（アクチュエータ）

・ $x^{(4)}$ : ステッピングモータ右（アクチュエータ）

動的対象の前後運動は (1) サイン波 (2) ロジスティック写 像 (3) 乱数の 3 パターンを用意する. 動的対象の両ステッ ピングモータの速度を $s_{R}$ と $s_{L}$ としたとき, それぞれ以 下のように定める.

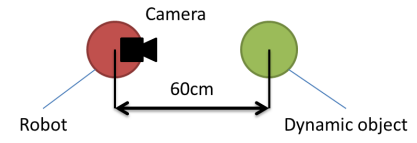

図 5 Position of robot and dynamic object

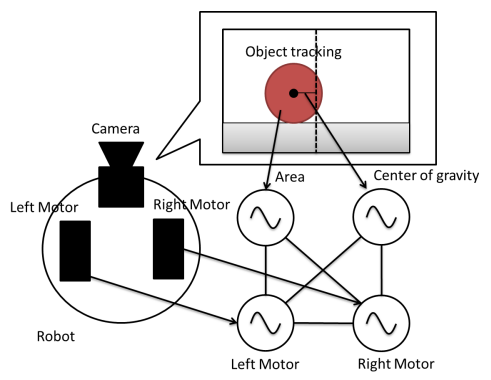

図 6 Sensors and actuators of robot and allocation to oscillators

(1) サイン波

$$
\begin{aligned}
& s_{R}=c_{v S} \sin \omega t \\
& s_{L}=c_{v S} \sin \omega t \\
& \omega=0.4 \pi
\end{aligned}
$$

(2) ロジスティック写像

$$
\begin{aligned}
& x_{L}(t)=a x_{L}(t-1)\left(1-x_{L}(t)\right) \\
& s_{R}=2 c_{v L}\left(x_{L}(t)-0.5\right) \\
& s_{L}=2 c_{v L}\left(x_{L}(t)-0.5\right) \\
& a=4.0
\end{aligned}
$$

(3) 乱数

$$
\begin{aligned}
& s_{R}=c_{v R} x_{R 1} \\
& s_{L}=c_{v R} x_{R 2}
\end{aligned}
$$

ただし, $x_{R 1}, x_{R 2}$ は区間 $(-1,1)$ の一様乱数とする. なお, 本研究では「摇らぎ」として, サイン波, ロジスティッ ク写像 (カオス), 一様乱数を考察し,「確率微分方程式」は 考察しない. 更に, この時面積のセンサ入力に特定の割合 のノイズをランダムで載せる事を考える. カメラで捉え ている動的対象の面積を $v$ としたとき，

$$
v^{\prime}=v+c_{r} x_{r} v_{\max }
$$

ただし,$x_{r}$ を区間 $(-1,1)$ の一様乱数とする. これを $c_{r}$ の 值を変えてそれぞれのパターンに加えることにする. 今回 の実験では振動子の状態值の計算には数值計算アルゴリズ ムとしてオイラー法を用い, $c_{r}=0.0(0 \%), c_{r}=0.3(30 \%)$, $c_{r}=0.6(60 \%)$ の 3つのースを比較する. 以降, 本研究に おいてオイラー法のステップ幅は, $d t=0.02(\mathrm{sec})$ とする. なお, サイン波の周期 5(sec) に対してこのステップ幅は 1/250 刻みに対応する.これにより, 同期に関して表 1 のよ うな結果が予想される. カオス的なふるまいをするロジス 
ティック写像やランダムな動きをする動的対象には同期す ることができない.一方で, サイン波のように周期的な運 動をする場合でも大きなノイズが載る場合では同期する ことは難しくなると予想される。このロボットは振動子の

\begin{tabular}{|l|c|c|c|}
\hline Noise & Sine wave & Logistic & Random \\
\hline $0 \%$ & $\bigcirc$ & $\times$ & $\times$ \\
\hline $30 \%$ & $\triangle$ & $\times$ & $\times$ \\
\hline $60 \%$ & $\times$ & $\times$ & $\times$ \\
\hline
\end{tabular}

O:able to synchronize $\triangle$ :unknown

$\mathrm{X}$ : unable to synchronize

表 1 Expected phenomenon from the aspect of synchronization

集合として制御されている.しかし, 実環境から受ける作 用や及ぼす作用の影響があり,一般にノイズが存在する場 合の振動子間の同期はその同期状態と非同期状態の分離 が困難であるため [Pikovsky 02], ロボットが動的対象に 同期したかどうか判断するのが難しい. そこで Multiscale entropy analysis(MSE 解析) を利用する. MSE 解析は生 体などで観測される時系列データの複雑さを測る手法で あり, その複雑さを表す指標を SampEn とする [Costa 05]. MSE 解析は短期から長期にわたる異なる時間スケール それぞれでの挙動の複雑性を測るものであり, 単純に同 じ動きを繰り返す場合にその複雑さを表す值 SampEn は 小さいものとなり,またランダムな動きをする場合には 短い時間スケールのみ SampEn が大きくなる傾向にある. MSE 解析は脳波の解析 [Takahashi 10] や, ネットワーク トラフィックの性質の解析に利用されている [Riihijarvi 09]. MSE解析は単変量の時系列データに対して用いられ るが, 本稿では多変量に対応した Multivariate multiscale entropy analysis(MMSE 解析) を用いる [Ahmed 12]. こ の実験ではロボットの 4 つの振動子の状態值を要素に持 つ 4 変量の時系列データに対して MMSE解析を行う。ノ イズの比率別の MMSE 解析の結果を図 8 に示す.この実 験では, 埋め込みベクトルの各要素 $m_{k}=2$, 時間遅れベク トルの各要素 $\tau_{k}=1$ 及び閾值 $r=0.15$ とし, 1 試行を実 時間で 8 分間として 3 パターンそれぞれにおいて 5 回の 試行を行った. 図 8 では 5 回の試行の平均值としてプロッ 卜している.ノイズの比率が $0 \%$, すなわちノイズがなく 動的対象がサイン波に従って移動する場合, Multivariate sample entropy(MSampEn) がロジスティック写像や乱数 に従って移動する場合に比べて大きくなっている.一方で ノイズの比率が $30 \%$ や $60 \%$ の場合は 3 パターンとも近 い值をとっている.ここで表 1 と照らし合わせると,サイ ン波に従い,かつノイズがない場合のみ MSampEn が大 きな值をとっており,すなわち動的対象と同期していると 考えられる場合のみに MSampEn が同期していない場合 と比べて大きな值をとっている.MSampEn が大きな值を とっているということは, 乱数や一定の周期運動など単純
な法則ではなく, 振動子群が互いに連携しつつ複雑な関 係を構築していることがわかる. 乱数が大きくなるほど MSampEn は短い時間スケールにおいての夕増加するは ずであるが, 短い時間スケールにおいても乱数の影響以上 に複雑な関係を構築し,かつ, 長い時間スケールにおいて もその複雑性を保っている. 同じロボットの制御アルゴ リズムにより実験を行っており, サイン波以外の動きをす る動的対象とも相互作用は起きているが, その MSampEn がサイン波に従い動的対象が動く場合よりも小さいこと から,生成された動きは単なる時系列情報の相関の高まり ではなく振動子間の相互作用により振動子群の複雑な挙 動が生み出されている, 寸なわち同期現象が引き起こされ ていると考えられる.

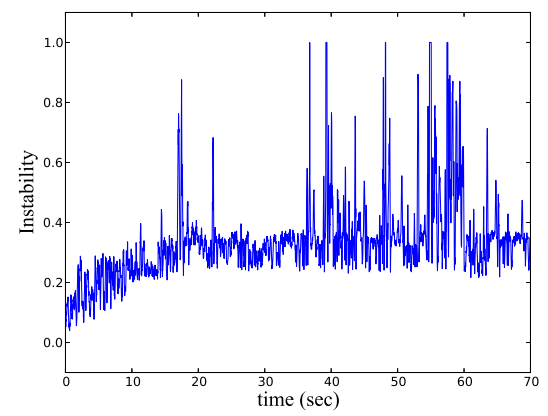

図 7 Instability of 1 trial when dynamic object moves according to sine wave(Noise:0\%)

このうち同期していると考えられるサイン波:ノイズ $0 \%$ のパターンの 1 試行の不安定度 $\varepsilon(t)$ の推移を図 7 に示す. このグラフから, 不安定度は最終的に $\varepsilon(t)=0.3$ 付近で安 定している.これよりも $\varepsilon(t)$ が大きくなる場合もすぐに また $\varepsilon(t)=0.3$ 付近まで減少させている (time $>10(\mathrm{sec}))$. 一方で初期の段階 $($ time $<10(\mathrm{sec}))$ では $\varepsilon(t)$ が 0.3 より小 さいにもかかわらず 0.3 付近まで増加している.これは動 的対象との同期と自身の不安定度の減少維持をバランス を取りながら両立している様子と考えられ, ある程度不安 定度が増大してでも動的対象との同期関係の構築を行っ ているためと考えられる。

\section{5. 強制同期を引き起こす対象に対する自律ロ ボット適用事例}

次に実際の応用事例として強制同期を引き起こす対象 に適応する自律ロボットシステムの構築を行う. まず $8 つ$ のチェックポイントからなるコースをロボットに走行さ せることを考える (図 9). 各チェックポイントには円形 領域が設定されており,その範囲にロボット頭上マーカが 侵入した時点で次のチェックポイントへとチェックポイン トが更新されるものとする.ロボットは 4 章と同様のロ ボットを用い，4つの振動子により制御するものとする. 


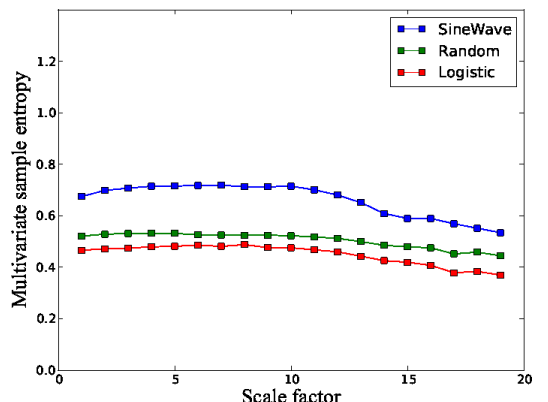

(a) Noise: $0 \%$

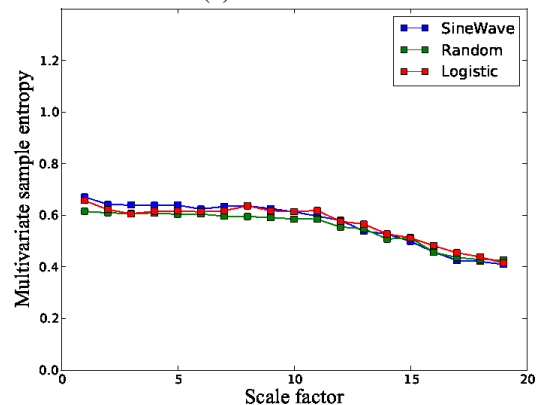

(b) Noise: $30 \%$

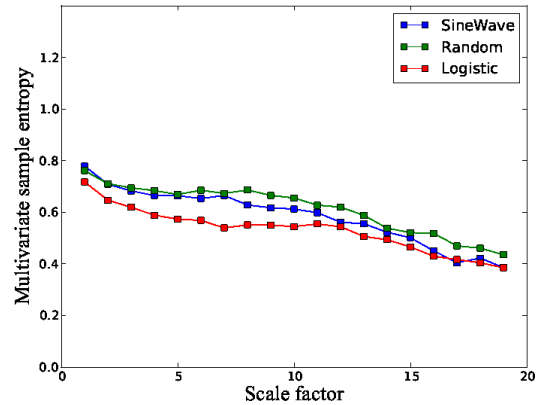

(c) Noise:60\%

図 8 MMSE analysis for 4-channel data containing oscillator state

ただし, 前方のカメラは利用せず, ロボット頭上マーカ位 置から計算される 2 量をそれぞれ 2 つ振動子に割り当 てるものとする. システム構成を図 10 に示す. 天井にカ メラが設置されており，PCに接続されている。このカメ ラ映像を元に, PC 上でマーカ位置計算を行い, ロボット の位置を得る.このとき, 先ほどの実験同様, ロボットの 両ステッピングモータの速度を PC から送信し, ロボット がその速度でステッピングモータを回転させる.このよう な, 真上からロボットのマーカトラッキングによりロボッ トの位置を得て, その值を元にロボットに行動を遠隔で指

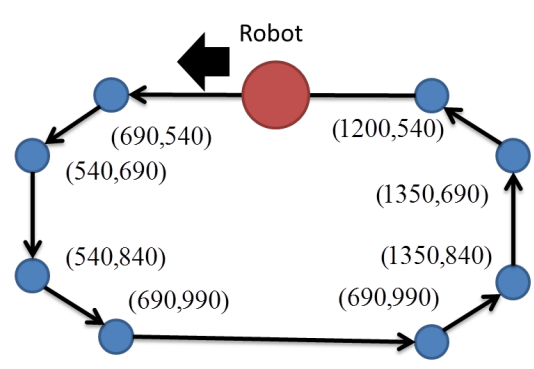

図 9 Course made of 8 checkpoints (unit:mm)
示する構成は, ロボカップサッカーなどロボットシステム にて広く利用されている。 ロボット頭上マーカ位置から

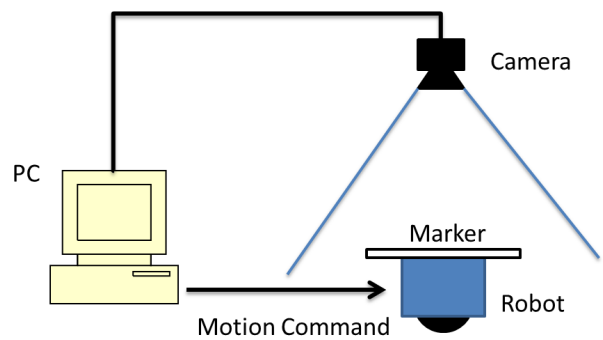

図 10 Experimental system configuration for forced synchronization application

計算される 2 量は次のように定められる. まず図 11(a)に 示すようにロボットの移動ベクトルとロボットから見た 現在のチェックポイントへの方向ベクトルのなす角 $\theta$ を センサ入力として与える.もう一方は, 図 11(b) のように 現在のチェックポイントと以前のチェックポイントを結ぶ 線分上からのロボットの距離を与える.アクチュエータ に割り当てた振動子 2 つは 4 章における実験と同様に左 右のステッピングモータの制御パラメータとする. 以降 アクチュエータを割り当てた振動子をアクチュエータ振 動子, センサを割り当てた振動子をセンサ振動子と呼ぶ.

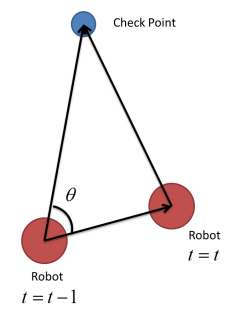

(a)

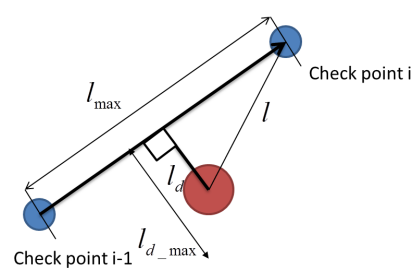

(b)
図 112 sensor definitions using robot camera. (a)Robot position and angle toward checkpoint, (b)Distance from course line and robot position

不安定度は $\theta=0, l_{d}=0$ が望ましいものとし,かつ現在の チェックポイントまでの距離が短いほどよいものとする ため次のように定義する.

$$
\varepsilon(t)=\frac{1}{3}\left(\frac{l}{l_{\max }}+\frac{l_{d}}{l_{d \_\max }}+\frac{\theta}{\pi}\right)
$$

この実験では仮想的な周期外力を導入する. そのため, 左 右のステッピングモータの各速度を $s_{R}, s_{L}$ をこの実験で は次のように定義する.

$$
\begin{aligned}
& s_{R}=x^{(4)}\left(s_{\max }-s_{\min }\right)+s_{\min }+s_{R}^{\prime} \\
& s_{L}=x^{(3)}\left(s_{\max }-s_{\min }\right)+s_{\min }+s_{L}^{\prime} \\
& s_{R}^{\prime}=c_{e f} \sin \omega t
\end{aligned}
$$


ここで, $s_{R}^{\prime}=s_{L}^{\prime}$ の場合と $s_{R}^{\prime}=-s_{L}^{\prime}$ の 2 パターンの仮想 的な周期外力を与えることにする。この実験においても MMSE解析を行うために比較用にノイズを加えた試行も 行う.この実験では現在のチェックポイントと以前のチェッ クポイントを結ぶ線分上からのロボットの距離にノイズ を加えることとする.よって

$$
x^{(2)}=\frac{l_{d}+c_{r} x_{r} l_{d_{\max }}}{l_{d \_\max }}
$$

ただし $x_{r}$ は区間 $(-1,1)$ の一様乱数とする.また, 振動子 の割り当ては以下のようである.

- $x^{(1)}$ : チェックポイントへの角度（センサ）

- $x^{(2)}$ : チェックポイント間線分からの逸脱距離 (センサ)

・ $x^{(3)}$ : 左ステッピングモータ (アクチュエータ)

・ $x^{(4)}$ : 右ステッピングモータ (アクチュエータ)

今回の実験ではコースを一周するのを 1 試行とし,それぞ れのパターンにおいて 5 回の平均から MMSE 解析を行っ た.MMSE 解析では 4 つの振動子の状態值及び周期外力 からなる 5 変量データを用いて算出した. また $\omega=0.4 \pi$ とする. MMSE 解析の結果を図 12, 図 13 に示寸. $s_{R}^{\prime}=s_{L}^{\prime}$, $s_{R}^{\prime}=-s_{L}^{\prime}$ の両パターンにおいて短い時間スケールではほ とんど差異は見られないが，長い時間スケールにおいて はノイズがない場合に高い複雑性が見られる.すなわち, 乱数の影響などではなくある程度大きな時間周期におい てセンサを含めた振動子間が複雑に連携していることが わかる。

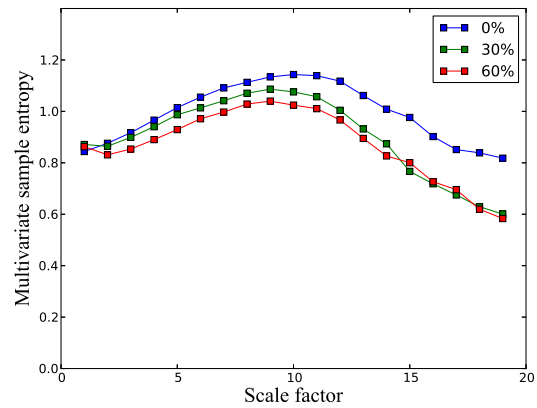

図 12 MMSE analysis for 5-channel data containing oscillator state and periodic external force and $s_{R}^{\prime}=-s_{L}^{\prime}$

ノイズがない場合の 1 試行の不安定度の推移を図 14 に示 す.垂直な線はチェックポイントが更新されたタイミング を示す。これより不安定度を下げる関係を発見できてい ることがわかる。また例として, $s_{R}^{\prime}=-s_{L}^{\prime}$, Noise:0\%の 1 試行のロボットの軌跡を図 15 に示す。更に,この実験は 仮想的な周期外力の周期が明確にわかる実験であるため, 周期外力から見たアクチュエータ振動子のリターンマッ プをプロットすることが可能である. そこで, 各アクチュ エータ振動子に対するリターンマップを図 16 に示す.リ ターンマップは $i$ 回目にある振動子の位相が 0 となった ときの別の振動子の位相を $\Delta \phi_{i}$ とし, 横軸に $\Delta \phi_{i}$, 縦軸に

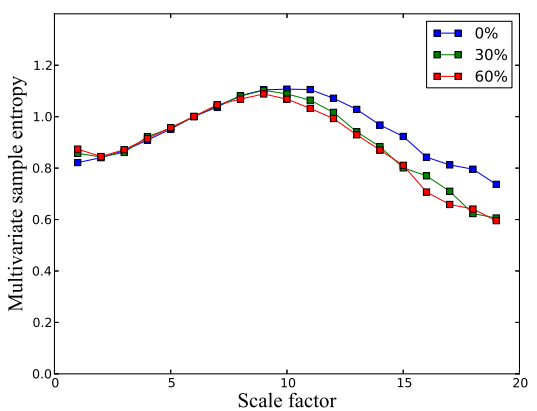

図 13 MMSE analysis for 5-channel data containing oscillator state and periodic external force and $s_{R}^{\prime}=s_{L}^{\prime}$

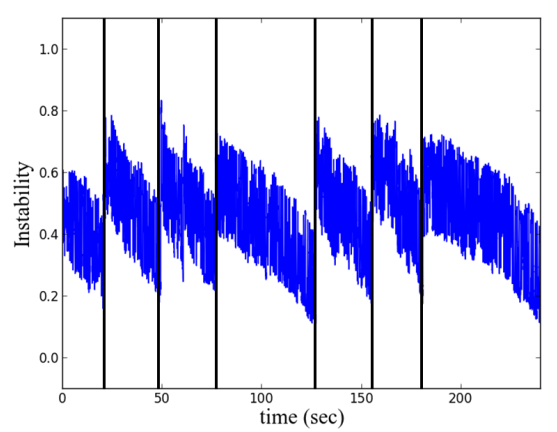

図 14 Instability of 1 trial in $0 \% \operatorname{noise}\left(s_{R}^{\prime}=-s_{L}^{\prime}\right)$

$\Delta \phi_{i+1}$ をプロットしたものとする.これらより, 図中円に 示すように $\Delta \phi_{i+1}=\Delta \phi_{i}$ 上にクラスターが見受けられる ため, 周期外力とアクチュエータが同期していることがわ かる.

\section{6. 相互同期を引き起こす対象に対する自律ロ ボット適用事例}

最後に相互同期を引き起こす対象に適応する自律ロボッ トシステムの構築を行う.まず 15 のチェックポイントか らなる半円状のコースをロボットに荷物を引かせて走行 させることを考える. 各チェックポイントの設定は座標を 除き 5 章と同様である. チェックポイントは半径 525(mm)

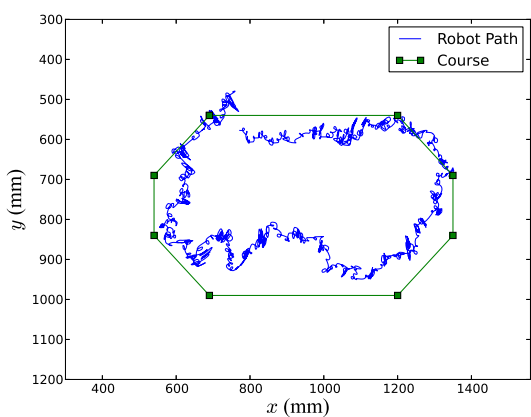

図 15 Example of robot path in 1 trial in $0 \%$ noise and $s_{R}^{\prime}=-s_{L}^{\prime}$ 


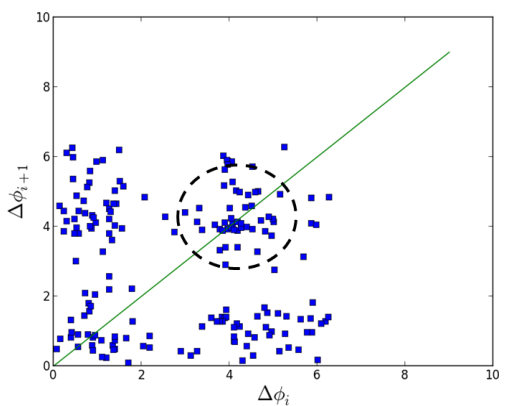

図 16 Return map between oscillator 3 and periodic external force when $s_{R}^{\prime}=-s_{L}^{\prime}$

の半円を 15 分割したものとして定める.ただし, 荷物にも マーカをつけ, 荷物がコースから逸脱しないようにロボッ トに走行させる.ロボットと荷物は $20 \mathrm{~cm}$ の紐で互いに 連結されており,この紐を介してロボットの動きが荷物に 反映されるようになっている.荷物には下部に滑車が取り 付けられており,ロボットから力を受けて滑らかに移動す る.ロボットの制御に用いる振動子は 5 章の実験と同様の ものを用意し,更に図 18 のように現在のチェックポイン トと以前のチェックポイントを結ぶ線分上からの荷物の 距離を割り当てる振動子を追加する (図 17:Oscillator 5). 不安定度も5 章のものに荷物の逸脱度を追加し(図 18), 次のように正規化する.
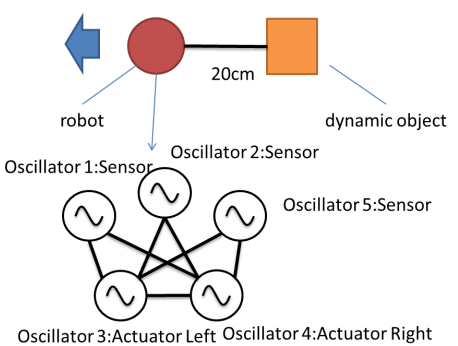

図 17 Oscillator allocation for robot and trailer

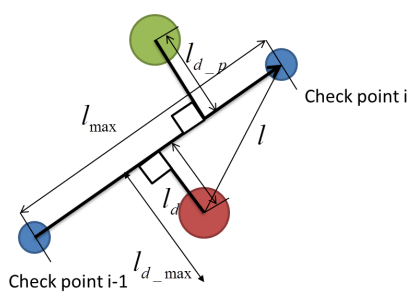

図 18 Distance from course line and trailer position

$$
\varepsilon(t)=\frac{1}{4}\left(\frac{l}{l_{\max }}+\frac{l_{d}}{l_{d \_\max }}+\frac{l_{d_{\_} p}}{l_{d \_\max }}+\frac{\theta}{\pi}\right)
$$

同様に MMSE 解析による同期判定を行うためにセンサ 振動子にノイズを載せる.ノイズの載せ方は

$$
x^{(5)}=\frac{l_{d_{-} p}+c_{r} x_{r} l_{d \_ \text {max }}}{l_{d \_ \text {max }}}
$$

ただし $x_{r}$ は区間 $(-1,1)$ の一様乱数とする. また, 振動子 の割り当ては以下のようである.

・ $x^{(1)}$ : チェックポイントへの角度（センサ）

- $x^{(2)}$ : チェックポイント間線分からの逸脱距離 (センサ)

・ $x^{(3)}$ : 左ステッピングモータ（アクチュエータ）

・ $x^{(4)}$ : 右ステッピングモータ (アクチュエータ)

- $x^{(5)}$ : チェックポイント間線分からの荷物の逸脱距離 (センサ)

今回の実験ではコースを半円状にまわるのを 1 試行とし， それぞれのパターンにおいて 5 回の平均を算出した (図 19). 5 つの振動子の状態值からなる 5 変量データに対

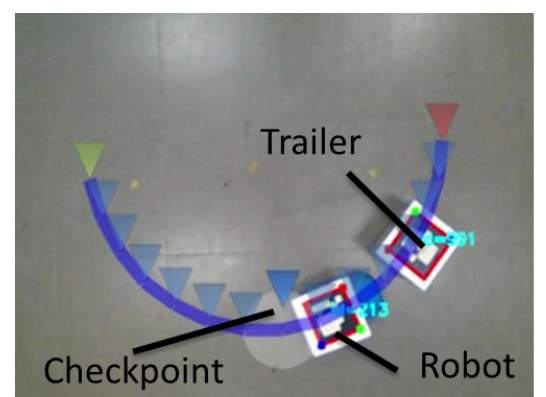

図 19 Robot, trailer and checkpoints in experimental field

しての MMSE 解析の結果を図 20 に示す.この場合も 5 章の場合と同様に小さなスケールではほとんど差異は見 られないが, 大きなスケールにおいてノイズがない場合 に複雑性が見られる.すなわち, 乱数の影響などではなく ある程度大きな時間周期においてセンサを含めた振動子 間が複雑に連携していることがわかる.またその值及び スケールごとの MSampEn の推移は 5 章のものとは異な り, 状況に合わせた同期関係を構築していることがわか る。ノイズがない場合の 1 試行の不安定度の推移を図

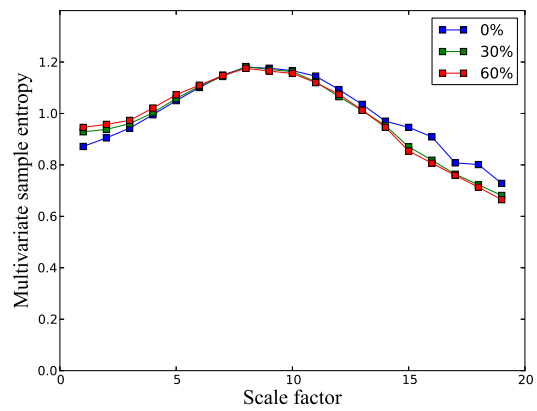

図 20 MMSE analysis for 5-channel data containing oscillator state

21 に示す. 垂直な線はチェックポイントが更新されたタ イミングを示す。これより不安定度を下げる関係を発見 できていることがわかる.また例として, Noise:0\%の 1 試 行のロボットの軌跡を図 22 に示す. 


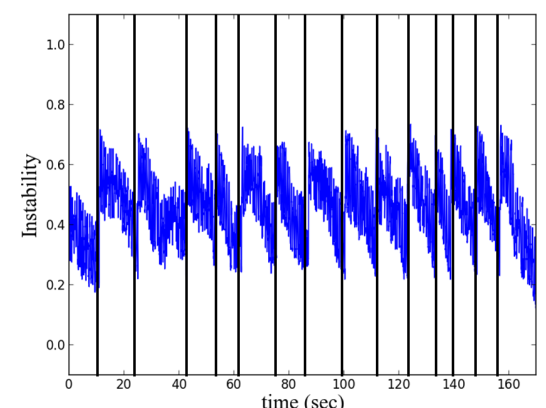

図 21 Instability of 1 trial in $0 \%$ noise

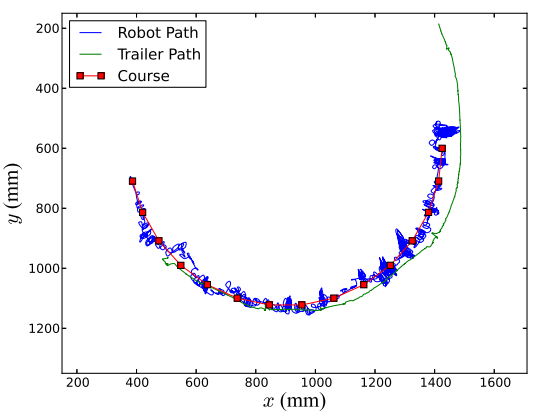

図 22 Example of robot path in 1 trial in $0 \%$ noise

\section{7.おわりに}

本稿では, ロボットを仮想的な振動子の集合として実装 し, 周囲環境に同期し関係を安定化させつつ, 自身の活動 を維持する働きを創発させる手法の動的対象への効果を 確認した. 静的対象への適応 [山内 15] における結果と合 わせて, 静止物, 何らかの規則性を持つもの, 周期性を持 つものなど幅広い対象への適応が可能であることを示し た.これにより, ロボットを取り巻く周囲環境の安定化に よる問題の簡単化やロボットの活動範囲及び対処能力の 向上の可能性がある. 今後は, 複数の微分方程式の求解ア ルゴリズムを用いた計算の比較による, 振動子間で引き起 こされている複雑な同期現象の詳細な分析を行うととも に,この手法を基盤として学習メカニズムとの融合など 更なる応用について検討を行う.

\section{$\diamond$ 参 考 文 献 $\diamond$}

[Ahmed 12] Ahmed, M. U. and Mandic, D. P.: Multivariate multiscale entropy analysis, Signal Processing Letters, IEEE, Vol. 19, No. 2, pp. 91-94 (2012)

[Costa 05] Costa, M., Goldberger, A. L., and Peng, C.-K.: Multiscale entropy analysis of biological signals, Physical Review E, Vol. 71, No. 2, p. 021906 (2005)

[Kleidon 05] Kleidon, A. and Lorenz, R.: 1 Entropy production by earth system processes, in Non-equilibrium Thermodynamics and the Production of Entropy, pp. 1-20, Springer (2005)

[Pikovsky 02] Pikovsky, A., Rosenblum, M., and Kurths, J.: Synchronization: A Universal Concept in Nonlinear Sciences (Cambridge Nonlinear Science Series), Cambridge University Press (2002)
[Riihijarvi 09] Riihijarvi, J., Wellens, M., and Mahonen, P.: Measuring complexity and predictability in networks with multiscale entropy analysis, in INFOCOM 2009, IEEE, pp. 1107-1115,IEEE (2009)

[Saigusa 08] Saigusa, T., Tero, A., Nakagaki, T., and Kuramoto, Y.: Amoebae anticipate periodic events, Physical Review Letters, Vol. 100, No. 1, p. 018101 (2008)

[Sassone-Corsi 98] Sassone-Corsi, P.: Molecular clocks: Mastering time by gene regulation, Nature, Vol. 392, pp. 871-874 (1998)

[Strogatz 03] Strogatz, S. H.: SYNC: The Emerging Science of Spontaneous Order, Hyperion, 1 edition (2003)

[Takahashi 10] Takahashi, T., Cho, R. Y., Mizuno, T., Kikuchi, M., Murata, T., Takahashi, K., and Wada, Y.: Antipsychotics reverse abnormal EEG complexity in drug-naive schizophrenia: A multiscale entropy analysis, Neuroimage, Vol. 51, No. 1, pp. 173-182 (2010)

[山内 15] 山内 翔, 川村秀憲, 鈴木 恵二 : 恒常性創発にむけた自 発的同期に基づく振動子の集合体による自律制御, 人工知能学会 論文誌, Vol. 30, No. 1, pp. 1-11 (2015)

[蔵本 07] 蔵本 由紀: 非線形科学 (集英社新書 408G), 集英社 (2007)

[担当委員：我妻 広明]

2015 年 6 月 15 日 受理

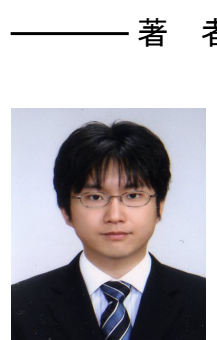

\section{者紹介}

\section{山内 翔}

1988 年 10 月 27 日生. 2011 年 3 月北海道大学工学部情 報エレクトロニクス学科卒業. 2014 年同大学院情報科学 研究科複合情報学専攻複雑系工学講座博士後期課程修了。 2015 年より公立はこだて未来大学. 2014 年より日本学術 振興会特別研究員. 自律ロボットシステムの研究に従事.

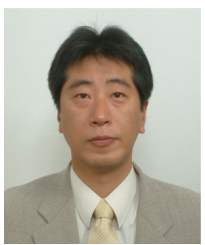

\section{鈴木 恵二(正会員)}

1966 年 2 月 22 日生. 1993 年 3 月北海道大学大学院工学 研究科精密工学専攻博士後期課程修了. 現在, 公立はこだて 未来大学教授. 知能情報学, 複雑系, 自律システム, 観光情 報に関する研究に従事. 正会員, 情報処理学会, OR 学会, 日 本機械学会, 日本ロボット学会, 各会員. 